\title{
Correction to: Innovation policy mix: mapping and measurement
}

\author{
Dirk Meissner $^{1}$ (D) $\cdot$ Sandrine Kergroach ${ }^{2}$
}

Published online: 19 December 2019

(c) Springer Science+Business Media, LLC, part of Springer Nature 2019

\section{Correction to: The Journal of Technology Transfer https://doi.org/10.1007/s10961-019-09767-4}

The original version of this article unfortunately contained a mistake. The Disclaimer was missing in the article. It is given below.

Disclaimer: The opinions expressed and arguments employed herein are those of the authors and do not necessarily reflect the official views of the OECD or of the governments of its member countries.

Publisher's Note Springer Nature remains neutral with regard to jurisdictional claims in published maps and institutional affiliations.

The original article can be found online at https://doi.org/10.1007/s10961-019-09767-4.

Dirk Meissner

dmeissner@hse.ru

Sandrine Kergroach

Sandrine.kergroach@oecd.org

1 National Research University Higher School of Economics, Moscow, Russia

2 Organization for Economic Cooperation and Development, Paris, France 